\title{
PROFESSIONAL PROFILE, LEGAL OBLIGATIONS, AND CONDUCT OF ORTHODONTISTS IN TERMS OF LITIGATION PREVENTION
}

\author{
PERFIL PROFISSIONAL, OBRIGAÇÕES JURÍDICAS E CONDUTAS DOS \\ ORTODONTISTAS FRENTE À PREVENÇÃO DE LITÍGIOS
}

\section{Vinícius Lima de ALMEIDA ${ }^{\mathbf{1}}$; Armando Koichiro KAIEDA ${ }^{2}$; Luanderson Oliveira SILVA ${ }^{\mathbf{1}}$; José Lucas Sani de Alcântara RODRIGUES ${ }^{1}$; Daiana BROLL ${ }^{3}$; Carlos Eduardo Palanch REPEKE ${ }^{4}$; Luiz Renato PARANHOS ${ }^{5}$}

1. Department of Dentistry, Federal University of Sergipe, Lagarto, SE, Brazil; 2. Department of Social Dentistry, Faculty of Dentistry of Piracicaba, State University of Campinas, Piracicaba, SP, Brazil; 3. Health Science Program, Federal University of Sergipe, Aracaju, SE, Brazil; 4. Professor, Department of Dentistry, Federal University of Sergipe, Lagarto, SE, Brazil. 5. Professor, Department of Dentistry, Federal University of Sergipe, Lagarto, SE, Brazil. paranhos@ ortodontista.com.br

\begin{abstract}
Orthodontic treatment requires ethical and legal attitudes from professionals since the first contact with the patient. Thus, this study assessed professional profile, legal obligations in provision of care, and the conduct of orthodontists in terms of litigation prevention during their professional practice. Questionnaires were emailed to 1653 Brazilian orthodontists, asking for information such as: age, gender, graduate orthodontic education, time of work in orthodontics, place of graduate education, time since graduation, and information regarding the legal criteria involved in the orthodontic treatment. Data were tabulated using absolute and relative frequencies. The chi-square test $(\mathrm{p}<0.05)$ was used to verify the association among nominal qualitative variables. Only 163 orthodontists participated in the study, wherein men represented $60.5 \%$ and women $39.5 \%$ of the sample. It was clear that professionals most recently graduated are the ones that mostly use the care provision contract, and the ones that mostly request teleradiographs. The female gender offered more treatment options, clarified the estimated treatment time more often, and was less involved in legal issues. On the other hand, the male gender requested cephalometry more often. Most professionals request the control radiograph, and all of them file the medical records of patients. Few professionals use the professional liability insurance. The results of the present study indicate a highly heterogeneous professional profile. The female gender dominates the field of expertise, and they seem to be more careful regarding legal obligations.
\end{abstract}

KEYWORDS: Orthodontics. Dental Legislation. Legal Responsibility. Dental Ethics.

\section{INTRODUCTION}

Orthodontic treatment is important for the esthetic and functional rehabilitation of the masticatory system (CRUZ et al., 2004; LIMPANICHKUL et al., 2006), as well as the complexity of diagnosis and treatment requires ethical and legal attitudes from the professional since the first contact with the patient (FERNANDES; CARDOZO, 2004). With the enactment of Law 8.078 of 1990, known as the Brazilian Consumer Protection Code (BRAZIL, 1991), individuals began to claim their rights in court more often, considering this legislation made them the weakest side of the relationship (professional/patient) (SILVA et al., 2009; PARANHOS et al., 2011; SOARES; ARAUJO, 2013). Thus, when litigation occurs and the judge acknowledges the vulnerability of the consumer, the reversal of the burden of proof is declared in the discovery stage. The dentist, therefore suitor, takes on the risk of losing the cause if unable to prove the alleged facts.
In view of this problem, the professional should use protection resources, not letting oral agreements to prevail in the moments anticipating the professional practice (JERROLD, 2014). Authors affirm that the medical record of the patient is the most effective way to avoid litigation (MACIEL et al., 2003; BENEDICTO et al., 2010; PARANHOS et al., 2011); however, it is worth noting that this record should be well thought out, complete, and constantly updated. The documents composing the medical record consist of anamnesis, clinical evolution of treatment, photographic, radiographic, and tomographic images, informed consent form, as well as copies of prescriptions and medical certificates (GARBIN; GARBIN; LELIS, 2006; PARANHOS et al., 2011). Article 17 of the Brazilian Code of Dental Ethics (FEDERAL COUNCIL OF DENTISTRY, 2012. P. 7) reinforces: "It is mandatory to elaborate and maintain the medical record in a legible and updated manner, and to store it in its own file, physically or digitally."

Thus, when the orthodontic treatment is concluded, the possibility of handing out the 
medical record to the patient or guardian is legal and viable. The documents and exams requested to the patient, such as radiographs (outlined), photographs, and plaster models (by the volume occupied), may be handed out to the legitimate interested party - not to third parties -, with a delivery receipt properly signed (PARANHOS et al., 2013), and the professional may file these information digitally.

The average time of use of fixed appliances is from 24 to 36 months (LIMPANICHKUL et al., 2006). According to time and complexity of treatments, especially in adults, neglecting to produce a medical record is one of the main mistakes professionals make, because it invalidates their plea. Thus, this study assessed professional profile, legal obligations in provision of care, and the conduct of orthodontists in terms of litigation prevention during their professional practice.

\section{MATERIAL AND METHODS}

\section{Research ethical criteria}

This study was previously approved by the Research Ethics Committee in Human Beings (Protocol: 301570-09; CAAE: 0117.0.214.000.09).

\section{Design and type of study}

A prospective and cross-sectional study that used questionnaires with open, semi-open, and closed questions that were emailed to 1653 Brazilian orthodontists found at the Brazilian Association of Orthodontics and Facial Orthopedics website. The questionnaire included objective, subjective, and semi-subjective questions, allowing the plurality of information. Information about the professionals were requested, such as age, gender, graduate orthodontic education, time of work in orthodontics, place of graduate education, and time since graduation.

The second part of the questionnaire concerned the legal criteria involved in orthodontic treatment. The objective questions addressed the use of the dental care provision contract, whether the professional offered more than one plan for orthodontic treatment, whether the professional determined the treatment time for the patient, whether there had already been a legal issue with patients, and whether the dentist had a professional liability insurance.

The subjective questions investigated the professional conduct used for requesting the initial documentation.

The semi-subjective questions allowed verifying whether the professional used a control radiograph and, in the case of a true affirmative, investigating how often it was used; also, whether the orthodontic documentation was filed and, in the case of a true affirmative, investigating for how long it was filed.

\section{Data collection instrument and procedures}

To validate the data collection and estimate the time spent filling out the form, a pilot test was conducted $(n=15$; not included in the study) with special attention to the relevant aspects of its reliability, content and application in research.

Information about the reproducibility of the data collection instrument were obtained from a second application of the questionnaire to the 15 orthodontists who participated in the pilot study, with a one-week interval between applications. The association between both answer times was calculated using Spearman's association coefficient. From the 15 participants, eleven (73.33\%) answered both questionnaires identically. The values of Spearman's coefficient ranged between 0.07 and 1 . Overall, it could be concluded that there was a strong association between both times the professionals answered the questionnaire; thus, the reproducibility of this instrument may be considered satisfactory.

After the result of the pilot study, the questionnaires were delivered to the subjects of the research. In order to send the questionnaires, an email account was created at Google (Gmail), exclusively to send and receive the questionnaires (attached as a Word file, version 2003) along with other attachments (informed consent form and researcher disclaimer - also as a Word file, version 2003).

A total of 1653 valid emails were sent and the waiting time for answers was of up to 30 days. After 30 days, emails were sent again for the professionals who had not answered, and the waiting time was of an additional 15 days. After the total period, 163 questionnaires $(9.86 \%)$ were answered.

\section{Data analysis}

Spearman's association coefficient $(\mathrm{p}<0.05)$ was used to validate the pilot test.

Data were tabulated using absolute frequency (n) and relative frequency (\%). The chisquare test was used to verify the association among nominal qualitative variables. A significance level of $5 \%(p<0.05)$ was used in all of the tests.

All statistical procedures were performed on the software Statistica, version v.5.1 (StatSoft Inc., Tulsa, USA). 


\section{RESULTS}

\section{Professional profile of the sample}

Only $9.8 \%$ orthodontists participated in the study; despite the low collaboration, we got a sample of 163 professionals, wherein men represented $60.5 \%$ and women $39.5 \%$ of the sample. In addition, different professional profiles was observed, being possible to compare them. The average age was $39.9 \pm 10.3$ years ( 23 to 82 years old) and the average time of work in orthodontics was $13.0 \pm 9.0$ years ( 1 to 54 years). It was noted that $59 \%$ of professionals have specialization courses, while $23.5 \%$ have a Masters degree, and $16.7 \%$ have a Doctorate degree. Regarding time of work in orthodontics (classification performed from tertiles), it was notes that $35.9 \%$ of professionals have been working for less than 9 years, while $34 \%$ have been working from 10 to 16 years, and $30.1 \%$ for more than 16 years.
ALMEIDA, V. L. et al.

\section{Legal obligations in the provision of dental care}

Issues regarding legal obligations of orthodontists and their association with professional education, gender, and time of work in the field of expertise are shown in Table 1. An association between time since professional graduation and the use of a dental care provision contract was clear, considering that professionals who graduated in the last five years use the contract more $(86.6 \%)$; presenting 3.02 of odds ratio, one of three main ways to quantify how strongly the presence or absence of association property, demonstrating a greater chance of professionals with shorter period of service to guard legally. There was an association between offering more treatment options and gender, in which women offered more options.

Most professional estimate the treatment time, wherein women $(90.16 \%)$ and individuals most recently graduated $(92.3 \%)$ practiced it more actively.

Table 1. Frequency distribution regarding the use of dental care provision contract, offering more than one dental treatment plan, establishment of dental treatment time, and their associations with professional education, gender, and time of work in the field of expertise.

\begin{tabular}{|c|c|c|c|c|c|}
\hline & Yes (\%) & No $(\%)$ & $p$ & C.I. & O.R. \\
\hline \multicolumn{6}{|c|}{ Use of dental care provision contract } \\
\hline Specialization & $73(74.00)$ & $26(26.00)$ & & & \\
\hline Masters & $25(73.52)$ & $9(26.00)$ & 1.00 & 0.41 to 2.44 & 1.01 \\
\hline Doctorate & $20(83.00)$ & $4(17.00)$ & 0.43 & 0.17 to 1.79 & 0.56 \\
\hline Stricto sensu & $45(77.58)$ & $13(22.00)$ & 0.70 & 0.37 to 1.73 & 0.81 \\
\hline Male & $73(73.73)$ & $26(26.27)$ & & & \\
\hline Female & $25(73.52)$ & $9(26.48)$ & 1.00 & 0.41 to 2.44 & 1.01 \\
\hline 1 to 5 years & $33(86.84)$ & $5(13.16)$ & & & \\
\hline 6 to 19 years & $59(68.60)$ & $27(31.40)$ & $0.0442 *$ & 1.06 to 8.59 & 3.02 \\
\hline $20+$ years & $24(80.00)$ & $6(20.00)$ & 0.5178 & 0.45 to 6.04 & 1.65 \\
\hline \multicolumn{6}{|c|}{ Offering more than one treatment plan } \\
\hline Specialization & $81(81.81)$ & $18(18.19)$ & & & \\
\hline Masters & $28(82.35)$ & $6(17.65)$ & 1.00 & 0.34 to 2.67 & 0.96 \\
\hline Doctorate & $24(96.00)$ & $1(4.00)$ & 0.11 & 0.02 to 1.47 & 0.18 \\
\hline Stricto sensu & $52(88.13)$ & $7(11.87)$ & 0.37 & 0.23 to 1.55 & 0.60 \\
\hline Male & $76(78.35)$ & $21(21.65)$ & & & \\
\hline Female & $58(93.54)$ & $4(6.46)$ & $0.01 *$ & 0.08 to 0.07 & 0.24 \\
\hline 1 to 5 years & $33(84.61)$ & $6(15.39)$ & & & \\
\hline 6 to19 years & $74(87.05)$ & $11(12.95)$ & 0.78 & 0.27 to 2.39 & 0.81 \\
\hline $20+$ years & $26(83.87)$ & $5(16.13)$ & 1.00 & 0.2901 to 3.856 & 1.05 \\
\hline \multicolumn{6}{|c|}{ Establishment of treatment time for the patient } \\
\hline Specialization & $82(83.67)$ & $16(16.33)$ & & & \\
\hline Masters & $29(85.29)$ & $5(14.71)$ & 1.00 & 0.29 to 2.62 & 0.88 \\
\hline Doctorate & $20(80.00)$ & $5(20.00)$ & 0.76 & 0.41 to 3.91 & 1.28 \\
\hline Stricto sensu & $49(83.05)$ & $10(16.95)$ & 1.00 & 0.44 to 2.48 & 1.04 \\
\hline Male & $77(79.38)$ & $20(20.62)$ & & & \\
\hline Female & $55(90.16)$ & $6(9.84)$ & 0.08 & 0.15 to 1.11 & 0.42 \\
\hline 1 to 5 years & $36(92.3)$ & $3(7.70)$ & & & \\
\hline 6 to19 years & $67(78.82)$ & $18(21.18)$ & 0.0742 & 0.88 to 11.68 & 3.22 \\
\hline $20+$ years & $24(80.00)$ & $6(20.00)$ & 0.1630 & 0.68 to 13.17 & 3.00 \\
\hline
\end{tabular}

Fisher's exact test: Performed to access the odds of contract for orthodontic treatment, offering more than one treatment plan establishment of treatment time for the patient. OR: odds ratio; CI: confidence interval. ${ }^{*} \mathrm{p}<0.05$. 


\section{Conduct of professionals in terms of litigation prevention}

Table 2 shows that there is no association between time since professional graduation, gender, professional education and the use of a control radiograph; however, most professionals request this exam. Figure 1 shows a correlation between older professionals and the longer time to request the control radiograph $\left(p=0.017 ; \mathrm{r}^{2}=0.04\right)$. Table 3 clarifies that all of the orthodontists file the medical records of patients. Regardless of professional education and gender, all professionals filed the medical records from 5 to 12 years, as shown in figure $2(p>0.05)$.

Table 2. Frequency distribution regarding the use of radiographic control and their correlations with professional education, gender, and time of work in the field of expertise.

\begin{tabular}{llllll}
\hline & Yes $(\%)$ & No $(\%)$ & $p$ & C.I. & O.R. \\
\hline Specialization & $91(95.78)$ & $4(4.22)$ & & & \\
Masters & $32(96.96)$ & $1(3.04)$ & 1.00 & 0.07 to 6.60 & 0.71 \\
Doctorate & $25(96.15)$ & $1(3.85)$ & 1.00 & 0.09 to 8.51 & 0.91 \\
Stricto sensu & $57(96.61)$ & $2(3.39)$ & 1.00 & 0.14 to 4.50 & 0.79 \\
\hline Male & $88(94.62)$ & $5(5.38)$ & & & \\
Female & $59(98.33)$ & $19(1.67)$ & 0.4044 & 0.03397 to 2.620 & 0.2983 \\
\hline 1 to 5 years & $36(92.37)$ & $2(7.70)$ & & & \\
6 to 19 years & $76(96.24)$ & $3(3.80)$ & 0.65 & 0.11 to 4.44 & 0.71 \\
20+ years & $30(96.77)$ & $1(3.23)$ & 1.00 & 0.05 to 6.94 & 0.60 \\
\hline
\end{tabular}

Fisher's exact test: Regarding the use of radiographic control and their associations with professional education, gender, and time of work in the field of expertise. OR: odds ratio; CI: confidence interval. *p<0.05.

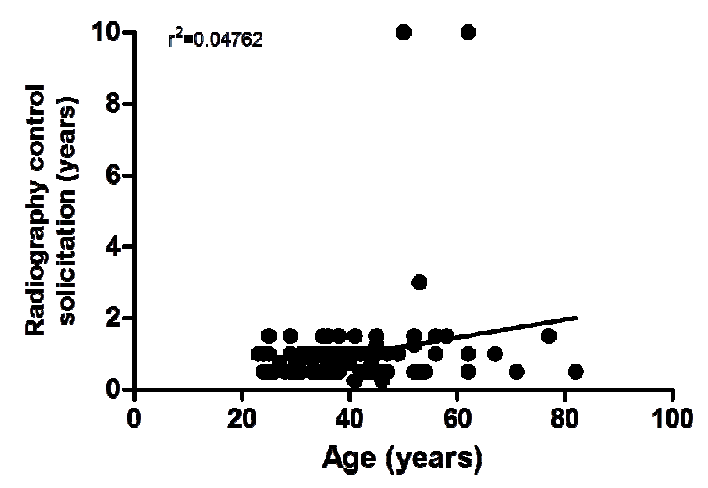

Figure 1. Analysis of time in years and radiography control solicitation. Value of $r^{2}$ of linear regression analysis are indicated in the graphs $(p=0.017)$.

Table 3. Frequency distribution regarding medical record storage and their associations with professional education, gender, and time of work in the field of expertise.

\begin{tabular}{lccccc}
\hline & Yes $(\%)$ & No $(\%)$ & p & C.I. & O.R. \\
\hline Specialization & 95 & 1 & & & \\
Masters & $32(100)$ & $0(0)$ & 1.00 & 0.03 to 24.66 & 0.97 \\
Doctorate & $29(100)$ & $0(0)$ & 1.00 & 0.04 to 27.22 & 1.07 \\
Stricto sensu & $61(100)$ & $0(0)$ & 1.00 & 0.02 to 12.92 & 0.51 \\
\hline Male & $91(98.90)$ & $1(1.10)$ & & & \\
Female & $61(100)$ & $0(0)$ & 1.00 & 0.01 to 12.38 & 0.49 \\
\hline 1 to 5 years & $39(100)$ & $0(0)$ & & & - \\
6 to 19 years & $78(100)$ & $0(0)$ & - & - & 3.24 \\
20+ years & $36(97.29)$ & $1(2.71)$ & 0.48 & 0.12 to 82.31 & \\
\hline
\end{tabular}

Fisher's exact test: Regarding medical record storage and their association with professional education, gender, and time of work in the field of expertise. OR: odds ratio; CI: confidence interval. *p<0.05. 


\section{Time of documentation storage}

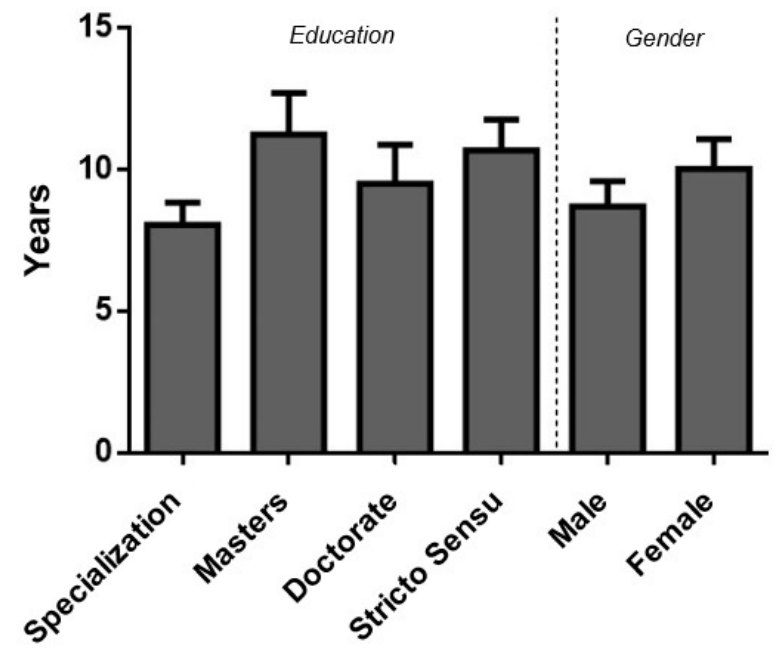

Figure 2. Non-relation between request for control radiograph and age of the orthodontist in years. T-test (Gender analysis); one-way ANOVA followed by Tukey's test (Education analysis; $\mathrm{p}<0.05$ ).

The association between professional education, gender, time of work in orthodontics and items pertaining to the initial documentation requested is shown in table 4 . There was an association between time of professional practice and the request for teleradiograph, in which individuals who were graduated for less than 5 years requested it more $(89.74 \%)$.
Table 4 also shows the association between gender and the request for cephalometric analysis in the initial documentation, in which the male gender (32.65\%) requests it more than the female gender, although most professionals do not request this analysis. The association between professional education and the request for hand-wrist radiograph showed that professionals with Stricto Sensu formation are the ones who mostly request it.

Table 4. Association between professional education, gender, time of work in orthodontics and items pertaining to the initial documentation requested.

\begin{tabular}{|c|c|c|c|c|c|c|}
\hline & & Yes (\%) & No (\%) & $\mathbf{p}$ & C.I. & O.R. \\
\hline \multirow{6}{*}{$\begin{array}{l}\text { Panoramic } \\
\text { Radiograph }\end{array}$} & Lato sensu & $79(79.00)$ & $21(21.00)$ & & & \\
\hline & Stricto sensu & $48(78.68)$ & $13(21.32)$ & 1.00 & 0.46 to 2.221 & 1.01 \\
\hline & Male & $76(77.5)$ & $22(22.5)$ & & & \\
\hline & Female & $51(79.68)$ & $13(20.32)$ & 0.69 & 0.36 to 1.78 & 0.81 \\
\hline & -5 years & 34 (87.17) & $5(12.83)$ & & & \\
\hline & $20+$ years & $23(74.19)$ & $8(25.81)$ & 0.22 & 0.92 to 1.49 & 1.17 \\
\hline \multirow{6}{*}{ Teleradiograph } & Lato sensu & $80(80.00)$ & $20(20.00)$ & & & \\
\hline & Stricto sensu & $43(70.49)$ & $18(29.51)$ & 0.18 & 0.80 to 3.49 & 1.67 \\
\hline & Male & $72(73.46)$ & $26(26.54)$ & & & \\
\hline & Female & $51(79.68)$ & $13(20.32)$ & 0.45 & 0.33 to 1.50 & 0.70 \\
\hline & - 5 years & 35 (89.74) & $4(10.26)$ & & & \\
\hline & $20+$ years & $20(64.51)$ & $11(35.49)$ & $0.01 *$ & 1.04 to 1.84 & 1.39 \\
\hline \multirow{6}{*}{ Photograph } & Lato sensu & $81(81.00)$ & $19(19.00)$ & & & \\
\hline & Stricto sensu & $49(80.32)$ & $12(19.68)$ & 1.00 & 0.46 to 2.33 & 1.04 \\
\hline & Male & 77 (78.57) & $21(21.43)$ & & & \\
\hline & Female & $53(82.81)$ & $11(17.19)$ & 0.55 & 0.33 to 1.70 & 0.76 \\
\hline & - 5 years & $34(87.17)$ & $5(12.83)$ & & & \\
\hline & $20+$ years & $22(70.96)$ & $9(29.04)$ & 0.13 & 0.95 to 1.58 & 1.22 \\
\hline
\end{tabular}




\begin{tabular}{clccccc}
\hline & Lato sensu & $81(81.00)$ & $19(19.00)$ & & & \\
& Stricto sensu & $49(80.32)$ & $12(19.68)$ & 1.00 & 0.46 to 2.33 & 1.04 \\
Male & $78(79.59)$ & $20(20.41)$ & & & \\
Model & Female & $52(81.25)$ & $12(18.75)$ & 0.84 & 0.40 to 1.99 & 0.90 \\
& -5 years & $32(82.05)$ & $7(17.95)$ & & & \\
& 20+ years & $24(77.41)$ & $7(22.59)$ & 0.76 & 0.83 to 1.34 & 1.06 \\
\hline & Lato sensu & $24(24.00)$ & $76(76.00)$ & & & \\
Cephalometric & Stricto sensu & $18(29.50)$ & $43(70.50)$ & 0.46 & 0.36 to 1.54 & 0.75 \\
Analysis & Female & $32(32.65)$ & $66(67.35)$ & & & \\
& - 5 years & $8(15.62)$ & $54(84.38)$ & $0.01 *$ & 1.18 to 5.80 & 2.61 \\
& 20+ years & $8(25.80)$ & $31(79.49)$ & & & \\
& Lato sensu & $57(57.00)$ & $43(43.20)$ & 1.00 & 0.47 to 2.56 & 1.10 \\
\hline \multirow{5}{*}{ Periapical } & Stricto sensu & $38(62.29)$ & $23(37.71)$ & 0.62 & 0.70 to 1.18 & 0.91 \\
Radiograph & Male & $56(57.14)$ & $42(42.86)$ & & & \\
& Female & $39(60.93)$ & $25(39.07)$ & 0.74 & 0.44 to 1.62 & 0.85 \\
& -5 years & $26(66.66)$ & $13(33.34)$ & & & \\
& 20+ years & $14(45.16)$ & $17(54.84)$ & 0.09 & 0.94 to 2.30 & 1.47 \\
\hline & Lato sensu & $7(7.00)$ & $93(93.00)$ & & & \\
& Stricto sensu & $11(18.03)$ & $50(81.97)$ & $0.03 *$ & 0.15 to 0.94 & 0.38 \\
& Male & $56(57.14)$ & $42(42.86)$ & & & \\
Hand-wrist & Female & $39(60.93)$ & $25(39.07)$ & 0.74 & 0.44 to 1.62 & 0.85 \\
Radiograph & - 5 years & $4(10.25)$ & $35(89.75)$ & & & \\
& 20+ years & $0(0)$ & $31(100.00)$ & 0.12 & Infinity & Infinity \\
\hline
\end{tabular}

Fisher's exact test: Between professional education, gender, time of work in orthodontics and items pertaining to the initial documentation requested. OR: odds ratio; CI: confidence interval. ${ }^{*} \mathrm{p}<0.05$.

\section{Legal issues vs. professional liability insurance}

The presence of legal issues during the professional clinical trajectory and their association with professional education, gender, and time of work in the field of expertise are present in table 5.
There was an association between gender and legal issues, in which female orthodontists $(95.09 \%)$ have less legal issues when compared to the male gender.

Table 5. Frequency distribution regarding legal issues with patients and their associations with professional education, gender, and time of work in the field of expertise.

\begin{tabular}{lccccc}
\hline & Yes $(\%)$ & No $(\%)$ & $\boldsymbol{p}$ & $\boldsymbol{C . I .}$ & $\boldsymbol{O . R}$. \\
\hline Specialization & $13(13.13)$ & $86(86.87)$ & & & \\
Masters & $3(8.82)$ & $31(91.18)$ & 0.76 & 0.41 to 5.85 & 1.56 \\
Doctorate & $3(12.00)$ & $22(88.00)$ & 1.00 & 0.29 to 4.23 & 1.10 \\
Stricto sensu & $6(10.16)$ & $53(89.84)$ & 0.62 & 0.47 to 3.72 & 1.33 \\
\hline Male & $17(17.34)$ & $81(82.66)$ & & & \\
Female & $3(4.91)$ & $58(95.09)$ & $\mathbf{0 . 0 2} *$ & $\mathbf{1 . 1 3}$ to $\mathbf{1 4 . 4 9}$ & $\mathbf{4 . 0 5}$ \\
\hline 1 to 5 years & $5(13.15)$ & $33(86.85)$ & & & \\
6 to 19 years & $12(14.11)$ & $73(85.89)$ & 1.00 & 0.30 to 2.83 & 0.92 \\
20+ years & $1(3.22)$ & $30(96.78)$ & 0.21 & 0.50 to 41.17 & 4.54 \\
\hline
\end{tabular}

Fisher's exact test: Regarding legal issues with patients and their relation with professional education, gender, and time of work in the field of expertise. OR: odds ratio; CI: confidence interval. ${ }^{*} \mathrm{p}<0.05$.

Most dentists (orthodontists) do not have a professional liability insurance, regardless of time since professional graduation, gender, and professional education. Male professionals (38.14\%) and the ones with more time since professional graduation - more than 20 years - $(38.7 \%)$ were more willing to apply for the professional insurance. 


\section{DISCUSSION}

The current population of Brazil is $204,075,215$ inhabitants, distributed in a territory of $8,515,767 \mathrm{~km}^{2}$ (BRAZILIAN INSTITUTE OF GEOGRAPHY AND STATISTICS, 2015), and in order to assist this population there are 276,971 dentists currently working, from which 23,673 are specialized in orthodontics and functional maxillary orthopedics (FEDERAL COUNCIL OF DENTISTRY, 2015). These numbers do not comprehend professionals dedicated to this field of expertise who are not specialists registered in the Brazilian Federal Council of Dentistry. With this whole supply of professionals, it is important to identify the legal care they are performing in terms of client services - nomenclature that should be employed after the Brazilian Consumer Protection Code (BRASIL, 1991).

According to Silva (SILVA, 1999), the dentist should work continuously according to technical, legal, and moral requirements that constitute the dental practice. However, this research showed that professionals who graduated in the last 5 years are the ones who mostly use the dental care provision contract. Therefore, it may be concluded that the time since professional graduation influences the compliance of legal obligations in terms of dental services. This situation seems predictable because older professionals use the tacit agreement over the express one. However, it is worth noting that article 3 of the Brazilian Consumer Protection Code classifies the dentist as a service "provider" (GAMA, 1999). Therefore, it may be inferred that the contract should be a pact between the professional and the patient (BITTAR, 1991), thus linked to the enforcement principle in which the objectives established should be faithfully complied (RODRIGUES, 2002).

Authors (PARANHOS et al., 2011) observed that $78 \%$ of the dentists interviewed established the treatment time for their patients. The present research also showed that the great majority of the participants in the study estimate treatment time; however, this attitude was more often practiced among professionals most recently graduated, agreeing with the influence of this variant on the matter of compliance of legal obligations and/or better patient/professional relationship. Here lies a thought: are recently graduated orthodontists acting more preventively because this issue is being more valued in postgraduation courses or is it a reflex of the media exposing legal issues against dentists? Perhaps even both theories together.

Professionals should offer more than one treatment option and clarify the respective prognoses, and allow the patient to choose the most favorable treatment type (BARROS, 1998; FRANÇA; RIBAS; LIMA, 2002). Moreover, according to the Brazilian Code of Dental Ethics, not properly clarifying treatment alternatives is an ethical breach (FEDERAL COUNCIL OF DENTISTRY, 2012). The present research verified that most professionals offer more than one treatment option. However, both the estimate of treatment time and the offer of more than one treatment option are practiced more actively by the female gender. Thus, it is possible to observe that the female gender is more careful regarding legal obligations.

Although there are orthodontic philosophies that do not use the cephalometric analysis, the present research did not address the philosophy used by each professional. Therefore, the fact that most professionals did not request the cephalometric analysis should be interpreted carefully, because although it seems to be neglect, it may also have been a decision established in the philosophy followed. Despite the low rate of cephalometry requests, panoramic radiographs, teleradiographs, and periapical radiographs are often requested. The present research showed that most professionals request control radiographs. Authors (BENEDICTO et al., 2010; PARANHOS et al., 2013) affirm that besides being mandatory items for orthodontic documentation, panoramic and incisors periapical radiographs should be requested every six months to follow-up on root resorption.

In a research performed with 56 orthodontists, most professionals affirmed they had never been involved in legal issues (MAIA et al., 2014). A similar result was found in the present research; however, the female gender presented less legal issues when compared to the male gender. This aspect shows again that women seem to be more careful in the clinical practice, perhaps through a good patient/professional relationship, thus avoiding litigations.

There is still not a consensus regarding the time of storage of the documentation present in dental records (VANRELL, 2009). In a research performed with 1469 orthodontists, $42.2 \%$ of professionals affirmed keeping the medical records for their entire professional career (SOARES; ARAUJO, 2013). However, in the present research, all orthodontists regardless of professional education and gender, file medical records from 5 to 
12 years. According to article 33 of the Brazilian Code of Civil Procedure, in Chapter VI (Evidences), the medical record is a document of probative force for the defense of the dentist (BRASIL, 1973). According to article 27 of the Brazilian Consumer Protection Code (BRASIL, 1990), the period of legal prescription regarding compensation for damages caused by the fact of product or service occurs in five years, and the period in question begins from the acknowledgment of the damage and its authorship. The lack of legal consensus regarding the time of filing for such documentation culminates in the time diversity for the storage of medical records. Professionals who do not file medical records throughout their careers take on the risk of lacking evidences in case there are legal issues whenever the orthodontist is no longer in possession of such documentation. Thus, authors (PARANHOS et al., 2011) say that the best conduct would be to file medical records for five years, and then return them with a detailed receipt, upon signature of the patient or legal guardian.

Because of the increase in lawsuits after the enactment of the Brazilian Consumer Protection Code (BRASIL, 1991), more dentists applied for the professional liability insurance (FRANÇA, 2004). However, the results of this research show that most dentists (orthodontists) do not apply for this insurance, and the ones that do are a portion of male professionals who have been graduated for more than 20 years. Although the insured party has a sense of "protection and tranquility", the professional insurance is not an absolute security, given it is only responsible for the financial part regarding trial costs and the reimbursement of the individual according to the sentence, not eliminating the vexation of a lawsuit (FRANÇA, 2004).

Because of the type of service provided to society, the dentist may be subjected to the involvement in a series of legal issues. It is important that professionals are more aware regarding the importance of complying with legal obligations in the provision of dental care. The dental care provision contract is a mean of legal protection and every professional should use it, including more than one treatment option with its respective prognoses.

\section{CONCLUSIONS}

The results of the present study indicate a highly heterogeneous professional profile. The female gender dominates the field of expertise and they seem to be more careful regarding legal obligations, which reflects in a lower number of litigations reported. In line with this fact, more male professionals apply for the civil liability insurance.

The conducts in terms of litigation prevention have an important association with time since professional graduation.

RESUMO: O tratamento ortodôntico requer atitudes éticas e legais dos profissionais desde o primeiro contato com o paciente. Assim, este estudo avaliou o perfil profissional, as obrigações jurídicas na prestação de serviços e as condutas dos ortodontistas frente à prevenção de litígios durante o exercício da profissão. Foram enviados questionários para e-mails de 1653 ortodontistas brasileiros, solicitando informações como: idade, gênero, formação ortodôntica, tempo de atuação na Ortodontia, local e tempo de formação e informações quanto aos critérios legais envolvidos no tratamento ortodôntico. Os dados foram tabulados com a utilização de frequência absoluta e relativa. Para verificar a associação entre variáveis qualitativas nominais foi utilizado o teste do qui-quadrado $(\mathrm{p}<0,05)$. Somente 163 ortodontistas participaram desse estudo, com os homens correspondendo a $60.5 \%$ e as mulheres a $39.5 \%$ da amostra. Ficou evidente que os profissionais com menor tempo de formação são os que mais utilizam o contrato de prestação de serviço odontológico e são os que mais solicitam telerradiografias. O gênero feminino mostrou oferecer mais opções de tratamento, esclarecer mais frequentemente a estimativa do tempo de tratamento e se mostrou menos envolvido em problemas jurídicos. Enquanto que o gênero masculino mostrou maior frequência na solicitação de cefalometria. A maioria dos profissionais solicita a radiografia de controle e todos arquivam o prontuário do paciente. Poucos profissionais utilizam o seguro de responsabilidade profissional. Os resultados do presente estudo apontam para um perfil profissional bastante heterogêneo. A especialidade tem predomínio do gênero feminino e este parece ser mais cauteloso em relação às obrigações jurídicas.

PALAVRAS-CHAVE: Ortodontia. Legislação Odontológica. Responsabilidade Legal. Ética Odontológica.

\section{REFERENCES}

BARROS, O. B. de. Como o cirurgião-dentista deve organizar-se para evitar processos. São Paulo: Raízes, 1998. p. 103. 
BENEDICTO, E. N.; LAGES, L. H. R.; OLIVEIRA, O. F.; SILVA, R. H. A.; PARANHOS, L. R. A importância da correta elaboração do prontuário odontológico. Odonto, São Bernardo do Campo, v. 18, n. 36, p. 41-50, 2010. Doi: 10.15603/2176-1000/odonto.v18n36p41-50

BITTAR, C. A. Responsabilidade civil médica, odontológica e hospitalar. São Paulo: Saraiva; 1991.

BRASIL. Lei nº 8.0878/90. Código de Defesa do Consumidor. Diário Oficial da União, Brasília, DF, 11 mar. 1991.

BRASIL. Lei n ${ }^{\circ}$. 5.869, de 11 de janeiro de 1973. Institui o Código de Processo Civil. Diário Oficial da União, Brasília, DF, 11 jan. 1973.

BRASIL. Lei nº . 8.078/90. Código de Defesa do Consumidor. Diário Oficial da União, 11 mar 1991.

BRAZILIAN INSTITUTE OF GEOGRAPHY AND STATISTICS. Population Projection of Brazil and the Federation Units. 2015. Available at: http://www.ibge.gov.br/apps/populacao/projecao/. Acessed: Apr 6, 2015. (Portuguese)

FEDERAL COUNCIL OF DENTISTRY. Code of Dentistry Ethics. Rio de Janeiro. 2012. (Portuguese)

FEDERAL COUNCIL OF DENTISTRY. Statistical data - Professionals. Available at: http://cfo.org.br/. Acessed: Dec 20, 2015. (Portuguese)

CRUZ, D. R.; KOHARA, E. K.; RIBEIRO, M. S.; WETTER, N. U. Effects of Low-Intensity Laser Therapy on the Orthodontic Movement Velocity of Human Teeth: A Preliminary Study. Lasers in Surgery and Medicine, New York, v. 35, n. 2, p. 117-120, 2004. Doi: 10.1002/lsm.20076

FERNANDES, F.; CARDOZO, H.F. Responsabilidade civil do cirurgião dentista: o pós-tratamento ortodôntico. Revista da Associação Brasileira de Odontologia, São Paulo, v. 12, n.5, p. 298-305, 2004.

FRANÇA, B. H. S. O Seguro de responsabilidade civil profissional: algumas orientações para a sua aquisição. Revista Clínica de Ortodontia Dental Press, Maringá, v. 3, n. 2, p. 34-35, 2004.

FRANÇA, B. H. S.; RIBAS, M. O.; LIMA, A. A. S. Orientações legais aos ortodontistas. Revista Clínica de Ortodontia Dental Press, Maringá, v. 2, n. 2, p. 25-31, 2002.

GAMA, H. Z. Direitos do consumidor: Código de Defesa do Consumidor referenciado e legislação correlata. 4a ed. Rio de Janeiro: Forense; 1999.

GARBIN, C. A. S.; GARBIN, A. J. I.; LELIS, R. T. Verificação das atitudes de cirurgiões-dentistas quanto à documentação de seus pacientes. Revista da Associação Paulista dos Cirurgiões Dentistas, São Paulo, v. 60, n. 6, p. 442-447, 2006.

JERROLD, L. Litigation and legislation. Accelerated orthodontics or accelerated liability? American Journal of Orthodontics and Dentofacial Orthopedics, St. Louis, v. 145 (4 Suppl), n. 145, p. S148-151, 2014. Doi: 10.1016/j.ajodo.2014.01.001

LIMPANICHKUL, W.; GODFREY, K.; SRISUK, N.; RATTANAYATIKUL, C. Effects of low-level laser therapy on the rate of orthodontic tooth movement. Orthodontics \& craniofacial research, Oxford, V. 9, N. 1, p. 38-43, 2006. DOI: 10.1111/J.1601-6343.2006.00338.X

MACIEL, S. M. L.; XAVIER, Y. M. A.; LEITE, P. H. A. S.; ALVES, P. M. A. A documentação odontológica e a sua importância nas relações de consumos: um estudo em Campina Grande - PB. Pesquisa Brasileira em Odontopediatria e Clínica Integrada, v. 3, n. 2, p. 53-58, 2003. 
MAIA, L. V. A.; PEREIRA, M. M. A. F.; PEDRO, A. C.; FERNANDES, M. M.; PARANHOS, L. R. Ethical and legal issues regarding the action and knowledge of orthodontists before civil liability. Acta Scientiarum. Health Sciences, Maringá, v. 36, n. 2, p. 251-256, 2014. Doi: 10.4025/actascihealthsci.v36i2.18733

PARANHOS, L. R.; MAGALHÃES, M. P. M.; FRANCIO, J.; TERADA, H.; ROSÁRIO, H. D.; SILVA, R. F. Time of guard of orthodontic records versus legal time for their prescription. Dental Press Journal of Orthodontics, Maringá, v. 18, n. 3, p. 113-117, 2013. Doi: 10.1590/S2176-94512013000300018

PARANHOS, L. R.; SALAZAR, M.; TORRES, F. C.; PEREIRA, A. C.; SILVA, R. F.; RAMOS A. L. Profile evaluation of orthodontics professionals as for their legal actions. Dental Press Journal of Orthodontics, Maringá, v. 16, n. 5, p. 127-134, 2011. Doi: 10.1590/S2176-94512011000500019

RODRIGUES, S. Direito Civil. 28. ed. São Paulo: Saraiva, 2002.

SILVA, M. da. A ética e a legislação odontológica aplicadas ao especialista em Ortodontia. In: INTERLANDI, Sebastião (Coord.). Ortodontia: bases para iniciação. São Paulo: Artes Médicas; 1999.

SILVA, R. H. A.; MUSSE, J. O.; MELANI, R. F. H.; OLIVEIRA, R. N. Surgeon dentist's civil liability: the technical assistant's importance. Revista Dental Press de Ortodontia e Ortopedia Facial, Maringá, v. 14, n. 6, p. 65-71, 2009. Doi: 10.1590/S1415-54192009000600009

SOARES, E. D.; ARAUJO, N. S.; Brazilian orthodontists and the legal issues involving their professional activity: a legal and behavioral proposal. Dental Press Journal of Orthodontics, Maringá, v. 18, n. 6, p. 6571, 2013. Doi: 10.1590/S2176-94512013000600011

VANRELL, J. P. Odontologia legal e antropologia forense. Rio de Janeiro: Guanabara Koogan; 2009. 